\title{
DEVELOPING TEACHING MATERIAL OF POETRY APPRECIATION BASED ON STUDENTS' COMPETENCY ANALYSIS
}

\author{
Satinem \\ Department of Indonesian Language and Literature Education, STKIP PGRI Lubuklinggau, Indonesia \\ E-mail: satinemyohana@gmail.com \\ Juwati \\ Department of Indonesian Language and Literature Education, STKIP PGRI Lubuklinggau, Indonesia \\ E-mail: watiaja56@ymail.com \\ Noermanzah \\ Postgraduate Program of Indonesian Language Education, University of Bengkulu, Indonesia \\ E-mail: noermanzah@unib.ac.id
}

\begin{abstract}
APA Citation: Satinem, Juwati, \& Noermanzah. (2020). Developing teaching material of poetry appreciation based on students' competency analysis. English Review: Journal of English Education, 8(2), 73-82. doi: 10.25134/erjee.v8i2.2707.
\end{abstract}

Abstract: The aim of this research was to develop the material of poetry appreciation at the Department of Indonesian Language and Literature Education of STKIP PGRI Lubuklinggau. The type of this research was Research and Development (R\&D) which was developed by the Dick, Carey, and Carey. Data collection was conducted through questionnaire, interviews, and tests. The data analysis and validity test were performed by using pretest and posttest of performance. The data is then processed by using a simple paired $\mathrm{t}$ test with the SPSS 20 program. The result of this research can be measured Asym.Sig. (2-tailed) 0,000... 0,05 . Therefore the value of t-hit 36,956 and t-tab 2,045 to (d) 17 and alpa 0,05, so it can be concluded t-hit <t-tab, so Ho has rejected, an Hi was accepted, its' meaning that the average value of students' ability to appreciate poetry after using instructional materials as a result of development was equal to 70 or more than 70. Thus, the model of instructional materials developed has been feasible and effective for lecturers.

Keywords: teaching material; poetry appreciation; competency analysis.

\section{INTRODUCTION}

The use of teaching material in poetry appreciation greatly affected the students' achievement. A number of studies on this have made us aware of optimizing the use of teaching materials so as to be able to boost the students' academic performance. Mahayana (2015) warned us that "The essence of literary learning is appreciation, and that only can be realized if teacher and student read those literary works." A teacher must have an innovative breakthrough in presenting teaching material that makes students can enjoy reading literature as a fun activity.

Warsiman (2015) believed that poetry appreciation material urges the students to find and comprehend the literature meaning of the literary works. The similar study was conducted by Setyorini \& Rizkiana (2019) shows that most students do not yet have poetry appreciation textbooks. Another research regarding poetry appreciation textbooks also conducted by Puspita, Andayani, Waluyo, \& Rohmadi (2017). The study explored that the use of poetry appreciation textbooks supports students' ideas regarding the critical thinking and self-appreciation. In addition, by implementing poetry appreciation in the class, it affects students nuance of learning to be more cooperative due to the discussion process of appreciating poetry itself.

Khatib (2011) explained the same statement of implementing poetry in learning process. The students tend to be active participants rather than being passive in order to make their own interpretation of the poetry. The results are clear that teaching materials have an important role to improve students' abilities while at the same time accustom them to study independently without any dependence on lecturers. Therefore, in order to increase the students' interest, it needs to create teaching materials that suitable for their needs. This research is based on the problem of the third semester students facing the difficulty to understand the meaning of poetry as a whole. Poetry requires special understanding from the reader. In this case, poetry has a choice of words with typography with connotation meaning so that the poetry appreciation teaching material is based on the analysis of competencies that are truly 
mastered by students (Khan, Jehanzeb, Ulah, \& Irfan 2016).

Mulyasa (2003) and Mulyasa (2017) also stated that competence is mastery of a task, skills, attitudes, and appreciation needed to support success. In this case, competence is seen as a set of knowledge, skills, and behaviors that must be possessed, internalized, mastered, and actualized by the teacher or lecturer in carrying out their professional duties. Competence is also the knowledge, skills, and basic values reflected in the habits of thinking and acting (Yayat, 2017). Kim, Xie, \& Cheng (2017) stated that teacher competency is often defined in literature as teachers' capacity to deal with a typical task or challenge (e.g., evaluation). It is also believed that teacher competences involve intellectual ability as well as affect-motivation characteristics to cope with real-world problems. The habit of thinking and acting consistently and continuously enables a person to be competent, in the sense of having basic knowledge, skills, and values to do something.

The indicators used to measure lecturers' competencies mostly consist of pedagogical competence, professional competence, personality competence, and social competence. However, there are only a few lecturers who aware that one of the basic pedagogic competence is creating their own teaching material (Fathorrahman, 2017). The lecturers who already created their teaching material can be seen as the one who have a great competency due to the fact that they put a lot of effort to revise the result of their teaching process. Anisa, Ansari, \& Solin (2019) add that the development of teaching materials is done as an effort to improve learning outcomes and determine the material based on the context of the situation that exists in schools. In addition, many lecturers are reluctant to create their teaching material that should be consisted of (1) instructional, (2) competences to be achieved, (3) supporting information, (4) exercises, (5) worksheets, and (6) evaluation as being stated by Lestari (2013). In accordance with the statement, Aji, Pratiwi \& Widiarti (2018) also added that it is important to create teaching material that contains material conceptualized which will be able to support a fun learning.

Prastowo (2011) states that many teachers still use conventional learning materials, teaching materials are bought by them without any effort. Furthermore, Depdiknas (2008) also wrote that teachers/lecturers need to develop their own teaching materials so that it will be in accordance with the curriculum, target characteristics, and problem-solving demands. A lecturer is required to be able to produce teaching materials in various sources through theoretical study as a basis for developing high-quality teaching materials. Lestari (2013) said that teaching materials are a set of learning materials referring to the curriculum in order to achieve competency standards and basic competencies.

In addition, Arifin \& Kusrianto (2013) assert that it is unfortunate if a teacher/lecturer has never composed their own teaching material once in their career. In this case, Nadeak \& Naibaho (2019) add that this kind of problem existed due to the limited number and the competitive nature, limited ability, and also lack of the enthusiasm of the lecturers themselves. Furthermore, the results from the interview, showed that lecturers used learning resources following the literature written in the RPKPS, without any assistance in preparation, and making their teaching materials.

Based on these facts, it has become an obligation for lecturers to design teaching materials themselves. Teaching materials that produce from the development will be more beneficial for students because the material delivered is in accordance with the wishes and the students' needs. By the development of teaching materials, students are able to dissect poetry in depth. Due to the fact that poetry belongs to the literature field, Puspita, Andayani, Waluyu, \& Rohmadi (2017) argue that literature reveals the human life, but the process of poetry creation requires the power of writers' imagination and creativity. In line with the statement, Sayuti (2002) says that poetry is an aesthetic work that utilizes unique language facilities. The statement is in line with Daniel (2013) and Noermanzah, Rais, \& Muslihah, 2013) argues that poetry is an artistic form of writing that meant to be woken up human's senses. Although Ritonga \& Halimatuhsa'diah (2019) argued that appreciating poetry can be seen as the literary activity with overflowing expression of thoughts and ideas, but based on observations in real life, reading books related to poetry in the library of STKIP PGRI Lubuklinggau are still very rare. It means that material related to literature especially poetry has characteristics itself, it is not a priority compared to the development of literature in general.

Satinem \& Juwati (2018) state that from the data obtained inform us that the highest score on the pretest was 85 the highest value and the lowest value was 40 , whereas in the posttest, the highest value was 95 and the lowest value was 60 . 
There was an increase in the ability of students after using the results of the development of teaching materials writing poetry with pictures. In addition, folklore teaching materials on poetry types have also been developed using a thematic approach and the results are effective in increasing folklore women poetry type students (Satinem, 2015). The poetry appreciation material based on competency analysis has never been conducted.

Based on these considerations, it is necessary to compile and develop teaching materials of poetry appreciation that are in accordance with the students' characteristics of STKIP PGRI Lubuklinggau. The problems of this research are as follows: a) What is the need for teaching materials of poetry appreciation according to lecturers and students; b) What is the model of teaching material of poetry appreciation developed for students; c) What is the feasibility of teaching material of poetry appreciation; d) What is the effectiveness of teaching materials of poetry appreciation?

\section{METHOD}

This research used Research and Development ( $R$ \& D) method. According to Sugiyono (2012), R $\& D$ is research method used to produce particular product and tested the effectiveness of the product. $\mathrm{R} \& \mathrm{D}$ was "a process used to develop and validate educational products" (Borg \& Gall, 2003). Thus, development research was a method for producing products or completing learning material products based on competency analysis. This research used developing model by Dick, Carey, \& Carey (2005). The development steps as follows 1) identification of learning objectives; 2) identification of learning; 3) identification of students' behavior and characteristics; 4) write specific learning goals; 5) write test items; 6) develop learning strategies; 7) developing learning materials; 8) carry out formative evaluations; 9) revision; 10) carry out summative evaluation.

The subject at this research was the third students' of STKIP PGRI Lubuklinggau as many as two classes. Furthermore, data collection techniques was carried out into 2 , quantitative data and qualitative data. The data analyzed qualitatively such as: 1) lecture appreciation poetry information; 2) input, responses and suggestions from the design of teaching materials; 3 ) information from small group respondents and; 4) suggested respondents. While quantitative data were obtained through a questionnaire of student needs and product assessment from 3 experts/validators.

There are three types of methods used, namely descriptive methods, evaluative methods, and experimental methods. Descriptive method is used to collect data about existing conditions, evaluative methods are used to evaluate the product development trial process, while the experimental method is used to test the reliability of the product produced (Sukmadinata, 2009). Product designs that have been evaluated by experts are tried on research subjects. The results of these treatments will know the level of product acceptance. In the final stage of development also used an experimental method, which is to measure the acceptability of products that have been revised on a larger scale.

\section{RESULTS AND DISCUSSION}

The results of the identification stated that in lectures the appreciation of poetry needs to be created that have teaching qualities. Lecturers not only rely on existing literature books but are able to create their own teaching materials.

Table 1. Gaps before and after doing the research

\begin{tabular}{|c|c|}
\hline Present & The expected conditions \\
\hline $\begin{array}{l}\text { 1. There was no teaching material for lecturing } \\
\text { appreciation of poetry. } \\
\text { 2. Students find it difficult to get reading material } \\
\text { that is relevant to the course. } \\
\text { 3. Students were fixated on the explanation of the } \\
\text { material by the lecturer. } \\
\text { 4. The appreciation power was still very low due } \\
\text { to the limited reading material. } \\
\text { 5. Students were less motivated to study poetry in } \\
\text { greater depth. } \\
\text { 6. Understanding of students was limited to } \\
\text { certain materials. }\end{array}$ & $\begin{array}{l}\text { 1. The availability of poetry appreciation teaching } \\
\text { materials in accordance with the wishes of } \\
\text { students and lecturers. } \\
\text { 2. Students are able to learn mandarially with } \\
\text { available teaching materials. } \\
\text { 3. Students are more creative in developing bright } \\
\text { ideas through teaching materials. } \\
\text { 4. Students are more creative in appreciating. } \\
\text { 5. Students become active and motivated to read } \\
\text { the material in depth. } \\
\text { 6. Students have very broad material insights. }\end{array}$ \\
\hline
\end{tabular}


After identifying at the research stage, information was obtained that STKIP-PGRI Lubuklinggau had implemented a competencybased curriculum or KKNI. The Semester Program Plan has been designed in accordance with applicable regulations. RPS is equipped with learning objectives, learning outcomes, a description of the material for each meeting and ends with training.

Table 2. Competencies that must be mastery by students on poetry appreciation courses

The Previous Lecturing Material

1. Definition of poetry
2. Intrinsic elements in poetry
3. Extrinsic elements
4. The nature and method of poetry
5. Structural approach
6. Semiotic approach
7. Cultural approach in literature
8. The literary religious approach
9. Intertextual in poetry
Lecturing Material in KKNI
1. Poetry and sonnets
2. Semiotic structural approaches and applications in poetry
3. Structural approach and application
4. Semiotic approach and its application
5. Structural genetic approach and application
6. Anthropological approach and application
7. Religious approach and application
8. Intertextual approach and application
9. Psychological approach and application in poetry
10. Strata norm approach and application

The function at this stage to determine the abilities of students, learning styles, interests, responses, and attitudes of students in lecturing activities. The response can be seen through the activity and interest in poetry. The developing was carried out on the description of the course for 1 semester, the learning objectives, and the learning outcomes. Learning objectives was carried out to measure student achievement and mastery of lecture material. The final step of development was to measure learning outcomes through formative and summative tests. The evaluation and revision stage was carried out through: a) evaluation of individual experts; b) small group evaluation; and c) field trials. Evaluations and revisions were made by linguists design experts, and material experts.

\section{Expert evaluation}

\section{Results of language validation}

The questionnaire consists of ten questions, namely: 1) Simplicity of sentence structure; 2) language is easy to understand; 3) information clarity; 4) the use of Indonesian language rules; 5) the language used is effective and efficient; 6) linkages between sentences and between paragraphs; 7) Completeness of supporting presentation; 8) use of EYD; 9) use of sentences; 10) straightforward sentences.

\section{Simplicity of sentence structure (unambiguous) and in accordance with Indonesian sentence patterns}

The sentence is stated as complete if it already has the S-P-O-K element. Based on the results of the study, it is stated that the third semester students have been able to write sentences that meet the S-P-O-K. They have been able to compile paragraphs that contain one main idea. Language validators provide an assessment that the sentences produced by students in poetry appreciation activities are very suitable with theoretical studies.

The results of the analysis need state that students and lecturers hope that the teaching materials of the research results are easily understood and in accordance with the RPS. It turned out that after evaluating the language validator, the teaching material produced was stated both in terms of language. The results of the validator assessment can be interpreted teaching materials produced from research can be developed into quality teaching materials. The results and responses from linguists on teaching materials can be seen in Table 3 .

Table 3. Recapitulation of language validator assessment

\begin{tabular}{ccc}
\hline Value Range & Percentage & Category \\
\hline $42-49$ & $\mathrm{P} \geq 85 \%$ & Excellent \\
$34-41$ & $65 \% \leq \mathrm{P}<85 \%$ & Good \\
$26-33$ & $40 \% \leq \mathrm{P}<650 \%$ & Moderate \\
$18-25$ & $25 \% \leq \mathrm{P}<40 \%$ & Less \\
$10-17$ & $10 \% \leq \mathrm{P}<25 \%$ & Very Less \\
\hline
\end{tabular}


From the results obtained it can be concluded that the component of language eligibility is included in the excellent category with a value of $46(92 \%)$. It can be interpreted as the quality of teaching materials in terms of language that has been tested and declared to be very good.

\section{Design/graphic validation results}

Teaching materials have been designed in accordance with the learning objectives contained in the syllabus and RPKPS. The purpose of the lecture has been mutually agreed between the lecturer and the student during the lecture contract. The validator stated that the teaching materials were very appropriate. Teaching materials consist of instructions for the use of teaching materials for lecturers and students, course descriptions, learning objectives, learning outcomes, and lecture appreciation lecture material for one semester. The validator stated that the teaching materials were very appropriate.

\section{Providing motivation}

Teaching materials have provided motivation for students. In teaching materials there were various methods to be able to dissect poetry. In addition, teaching materials use language that is easily understood and communicative. The validator stated that the teaching materials were very appropriate. Teaching materials have a stimulus and response for students. The validator states that teaching materials are very appropriate. Teaching materials have used the right type and size. Teaching materials have complete information in terms of content or lecture material. Teaching material was mutually agreed upon during the recovery contract. The validator stated that the teaching material developed was very appropriate.

The type of letter used was Times New Roman, with a size of 12 , and a space of 1.5 . The size and type of letters were in accordance with the standards required in writing scientific papers. The validator provides an assessment of the results of development in terms of size and type of letters said to be good.

\section{Complete illustrations of images}

Cover was designed according to the students' needs which attractive and full color. The cover of teaching materials was dominated by light blue combined with white. It looked a very contrasting color blend. The front cover was illustrated with a very neat and abundant pile of literary books. The picture contains an invitation to them to later become nerds. The validator provides an assessment that the teaching materials resulting from the development in terms of the accuracy of the illustrations in graphics, graphs, and tables are stated to be good.

The teaching material produced has a simple but elegant appearance. Light blue dominates teaching. A beautiful young woman is reading surrounded by various types of books. The validator gives an assessment that teaching material seen from physical appearance can be said to be very suitable. Paper used A4 with a thickness of 80 grams. Paper on teaching materials has been standardized with the rules of writing scientific papers. The paper was white and does not shine so it did not make the reader dazzled. Cover Blue combined with white made a very contrast. The shape of the cover was equipped with a picture of a woman who was pondering. Behind a beautiful girl there were various types of neatly arranged books, meaning that there was no day without reading. Design/graphic experts gave the following advice:

1) Add multiple images that match the content.

2) Made Boy Tex in the poem quoted.

3) Overall teaching materials were good can be used according to suggestions and revision.

Table 4. Recapitulation of design/graphic validator assessment

\begin{tabular}{ccc}
\hline Value Range & Percentage & Category \\
\hline $42-49$ & $\mathrm{P} \geq 85 \%$ & Excellent \\
$34-41$ & $65 \% \leq \mathrm{P}<85 \%$ & Good \\
$26-33$ & $40 \% \leq \mathrm{P}<650 \%$ & Moderate \\
$18-25$ & $25 \% \leq \mathrm{P}<40 \%$ & Less \\
$10-17$ & $10 \% \leq \mathrm{P}<25 \%$ & Very Less \\
\hline
\end{tabular}

From the results obtained it can be concluded that the component of design/graphic feasibility was included in the Very good category, which is $46(92 \%)$. The results of the evaluation of the validator can be interpreted that teaching materials are very well used for learning poetry appreciation.

\section{Content/material expert}

Teaching materials in accordance with the syllabus contained in the RPKPS were delivered at the beginning of the lecture contract. The 
validator provides an assessment that teaching materials were in accordance with the RPKPS so that they are declared good. Teaching materials according to student needs. The validator gives a good rating. The material contained in teaching materials was in accordance with RPKPS and has character values. The validator giving an assessment of teaching materials was stated to be very in accordance with the characteristics of the students.

Teaching materials provide benefits to add insight into science. Before the development of poetry appreciation teaching materials only used literature in the library. The validator provides an evaluation of the instructional materials the results of the development are expressed both in terms of conformity with the existing reality. The material on teaching materials has been equipped with exercises and examples of poetry appreciation activities. Training is given at the end of each subject. The validator gives an assessment of the teaching material in terms of the suitability of the material can be stated accordingly.

The material has been completed with the final evaluation and also the weighting of each question. The validator provides an assessment in terms of the suitability of the material with the final evaluation declared good. All material and appreciation activities contain new insights with various literary methods. Validator provides judgments in terms of insight into knowledge otherwise very appropriate.

Lecture material on teaching material was easy to understand and in accordance with the characteristics. The validator provides an assessment that the material was very appropriate. The material presented already has character values. The validator provides an assessment that teaching materials are very suitable for use. The material has a very high cultural value. The validator provides an assessment of teaching materials that were very culturally appropriate. The results of the material validator can be seen in Table 5.

Table 5. Recapitulation of the content validator's assessment

\begin{tabular}{ccc}
\hline Value Range & Percentage & Category \\
\hline $42-49$ & $\mathrm{P} \geq 85 \%$ & Excellent \\
$34-41$ & $65 \% \leq \mathrm{P}<85 \%$ & Good \\
$26-33$ & $40 \% \leq \mathrm{P}<650 \%$ & Moderate \\
$18-25$ & $25 \% \leq \mathrm{P}<40 \%$ & Less \\
$10-17$ & $10 \% \leq \mathrm{P}<25 \%$ & Very Less \\
\hline
\end{tabular}

The results of the assessment of the material of the overall results of the three validators can be validator can be interpreted that the teaching material produced was very good. Recapitulation seen in table 6.

Table 6. Recapitulation of evaluation of three validators

\begin{tabular}{ccccc}
\hline No. & Validator & Rating Result & Percentage & Category \\
\hline 1 & Linguist & 46 & $92 \%$ & Excellent \\
2 & Graphic Expert & 46 & $92 \%$ & Excellent \\
3 & Material Expert & 46 & $92 \%$ & Excellent \\
\hline & Average & 46 & $92 \%$ & Excellent \\
\hline
\end{tabular}

\section{Implementation of one to one evaluation}

Poetry appreciation courses are one of the advanced courses. They are allowed to take poetry appreciation courses after graduating from the literary theory course. This means that in theory all approaches used to analyze poetry have been mastered by students. The objectives to be achieved through this course are so that students will be able to study a number of literary theories for the final project. Teaching materials produced in the study, will be packaged into a book that has an ISBN. Student final assignments related to literature can cite books that have been produced in research.

The results of the implementation of the one to one test did not improve from the suggestions of the validators, this could mean that teaching materials could be used without revision and then a practical test would be carried out on small groups.

\section{Small group evaluation implementation}

The practicality of the teaching materials resulting from the development was carried out by means of one-to-one tests and small group evaluations. One to one evaluation was conducted by 
ENGLISH REVIEW: Journal of English Education

Volume 8, Issue 2, June 2020

interviewing 3 students. While the small group test evaluation was given the provision of a questionnaire containing the practical use of teaching materials. The results are very much in accordance with the percentage of $83 \%$.

\section{Implementation of broad trials}

The research was carried out in accordance with the R\&D stages. After several revisions in accordance with input from the validators and users of teaching materials, the teaching materials resulting from the development can be tested in broad groups. The results of the implementation of the test that the teaching material declared effective in terms of language, material, and in terms of design. The assessment criteria determined, students were declared able to appreciate poetry if the value obtained. From $t \geq$ 70 the results of data processing obtained an average value of 72.88 . There are 3 students who scored below 70. Students who scored an average above 70 totaled 14 people $(82,355)$. Based on these results it can be stated that the teaching material with the title "Appreciation Poetry: Theory, Approach and Application" is effectively used in Poetry Appreciation courses. The following describes the results in detail about the reliability, validity, and effectiveness of teaching materials developed.

The extensive trials were conducted to see the effectiveness of poetry appreciation teaching materials based on competency analysis. Furthermore, an evaluation of the effectiveness of the teaching materials resulting from the development can be seen from the results of the
p-ISSN 2301-7554, e-ISSN 2541-3643 https://journal.uniku.ac.id/index.php/ERJEE

Final Semester Examination test. Students were said to be able to appreciate poetry if they get a value of $\geq 70$. The average value of student poetry appreciation reaches 72.88 . There were 17 students taking the final test. Students who score below the average are 3 people $(17.65 \%)$, while those who score above the average are 14 people $(82.35 \%)$. Thus the teaching material titled "Poetry Appreciation: Theory, Approach, and Application" has been effectively used for lecturing appreciation of poetry. The following detailed results are described regarding the calculation of reliability, validity, and effectiveness by calculating SPSS.

Extensive trials were conducted to see the effectiveness of poetry Appreciation teaching materials based on competency analysis. Furthermore, an evaluation of the effectiveness of the teaching materials resulting from the development can be seen from the results of the Final Semester Examination test. Students were said to be able to appreciate poetry if they get a value of $\geq 70$. The average value of student poetry appreciation reaches 72.88 . There were 17 students taking the final test. Students who score below the average are 3 people $(17.65 \%)$, while those who score above the average are 14 people $(82.35 \%)$. Thus the teaching material titled "Poetry Appreciation: Theory, Approach and Application" has been effectively used for lecturing appreciation of poetry. The following detailed results are described regarding the calculation of reliability, validity, and effectiveness by calculating SPSS.

Table 7. Calculation of reliability, validity, and effectiveness

\begin{tabular}{lccccc}
\hline \multicolumn{5}{c}{ Descriptive Statistics } \\
\hline & $\mathrm{N}$ & Minimum & Maximum & Mean & Std. Deviation \\
\hline VAR00001 & 17 & 60.00 & 83.00 & 72.8824 & 8.13082 \\
Valid N (listwise) & 17 & & & & \\
\hline
\end{tabular}

\begin{tabular}{|c|c|c|c|c|c|c|}
\hline \multicolumn{7}{|c|}{ One-Sample Statistics } \\
\hline & & $\mathrm{N}$ & Mean & Std. Deviation & & Std. Error Mean \\
\hline VAROC & 001 & 17 & 72.8824 & 8.13082 & & 1.97201 \\
\hline \multicolumn{7}{|c|}{ One-Sample Test } \\
\hline \multicolumn{7}{|c|}{ Test Value $=0$} \\
\hline & & & & & \multicolumn{2}{|c|}{$95 \%$ Confidence Interval of the Difference } \\
\hline & $\mathrm{T}$ & Df & Sig. (2-tailed) & Mean Difference & Lower & Upper \\
\hline VAR00001 & 36.958 & 16 & .000 & 72.88235 & 68.7019 & 77.0628 \\
\hline
\end{tabular}




\begin{tabular}{llc}
\hline & One-Sample Kolmogorov-Smirnov Test \\
\cline { 3 - 3 } $\mathrm{N}$ & & VAR00001 \\
\cline { 2 - 2 } Normal Parameters ${ }^{\mathrm{a}}$ & Mean & 17 \\
& Std. Deviation & 72.8824 \\
Most Extreme Differences & Absolute & 8.13082 \\
& Positive & .179 \\
& Negative & .179 \\
Kolmogorov-Smirnov Z & & -.173 \\
Asymp. Sig. (2-tailed) & & .737 \\
a. Test distribution is Normal. & & .649 \\
\hline
\end{tabular}

After processing the data using the have been developed has exceeded the set Kolmogorov Smirnov Z One-Sample test, the average value of poetry appreciation was 72.8824 with a mean standard deviation of 8.13082. That is, the data are normally distributed with the Asym.Sig (2tailed) value of $0,000<0.05$. Thit values were 36.958 and $t$ tab was 2.045 for (d) 17 and alpha 0.05 . Based on the test results, then Ho is rejected and $\mathrm{Ha}$ is accepted. This can be interpreted that the average value of poetry appreciation after using teaching materials that

standards.

The minimum assessment standard of poetry appreciation courses is $\geq 70$. From the above table, it can be seen the average value of poetry appreciation of students is 72.88 . There were 3 students who scored below the established criteria $(17.65 \%)$ and 14 students $(82.23 \%)$ had scored above the set standard. Consider the following chart.

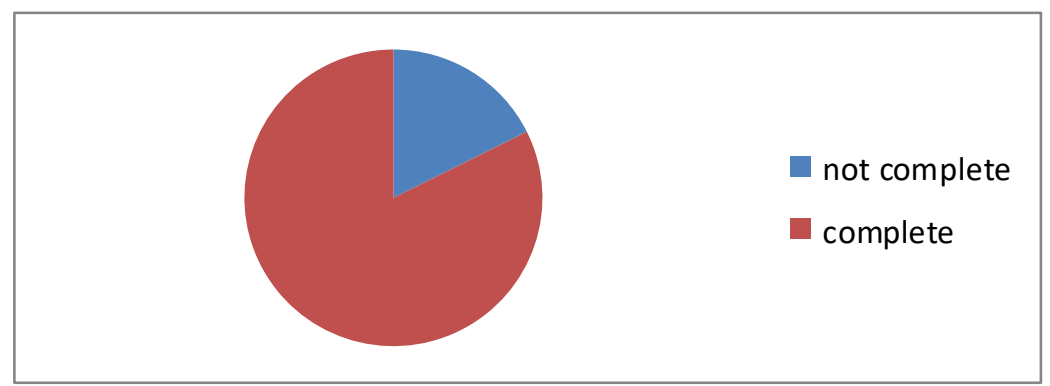

Figure 1. Percentage of completeness

Based on these data, the teaching materials resulting from the development are effective and can be used for a broad audience. This shows that competency-based Poetry Appreciation teaching materials that are prepared are able to provide students with an understanding of the meaning of poetry because poetry is built by simple word choices and unique line and line typography so as to present deep meaning (Khan et al., 2016). Poetry Appreciation teaching materials are also compiled by taking into account the competencies that must be mastered by students at the tertiary level, starting with the introduction of the nature of poetry, the characteristics of poetry, types of poetry, poetry writing techniques, and the development of poetry in the modern era, as well as examples of analytical results from the meaning of poetry. Particularly from several examples of the meaning of poetry in this teaching material provide students with direct understanding of how to write good poetry and understand the meaning of poetry (Noermanzah \& Friantary, 2019). In each material presented also provides learning experiences both cognitive, affective, and psychomotor through exercises (Yayat, 2017).

\section{CONCLUSION}

Some conclusions from the results of this development research are as follows. First, students and lecturers need teaching materials that are complete, interesting, and easy to understand to do poetry appreciation activities. Teaching materials are designed with an attractive cover. The design of teaching materials gives a cooler 
and neat impression. Book size that is not too large is more practical.

Second, the design has changed after evaluation by a validator and a colleague. The teaching materials already have completeness, namely: 1) there were instructions for the use of teaching materials both lecturers and students; 2) has an assessment rubric for each subject; 3 ) in accordance with the IQF curriculum; 4) have an interesting approach.

Third, the validators concluded that the poetry writing teaching material entitled "Appreciation of Poetry: Theory, Approach, and Application" was stated to be very appropriate $(92 \%)$ so that it could be used for Lubuklinggau STKIP-PGRI students. The validator also provides recommendations so that lecturers and students can use these teaching materials because teaching materials have been tested both in terms of language, graphics, and materials.

Fourth, teaching materials using $\mathrm{t}$-test statistical analysis with the SPSS program is effective. SPSS test results are normally distributed data, indicated by the value of Asymp.Sig. (2-tailed) $0.000<0.05$. As for the t-hit, it is valued of 36.958 and t-tab 2.045 for (d) 17 and alpha 0.05. Thus it can be concluded t-hit>ttab, so that Ho was rejected, and Hi was accepted, meaning that the average value of a student's ability to appreciate poetry after using teaching materials from the development is equal to 70 or more than 70 . Thus, the teaching material model developed has been feasible and effective from academic/expert studies, practically the teachers, and effective use in the field.

\section{ACKNOWLEDGEMENT}

This research is funded by STKIP-PGRI Lubuklinggau entitled "Development of Poetry Appreciation Subjects Based on Competency Analysis". Acknowledgments to the Lubuklinggau STKIP-PGRI Institute (2017 Budget Year Research Contract). Furthermore, gratitude was conveyed to reviewers who have read, corrected, and provided inputs on this paper.

\section{REFERENCES}

Aji, G. P., Pratiwi, Y., \& Widiarti, N. (2018). Development of instructional materials writing poetry based on nature tourism for poetry learning. ISSLAC: Journal of Intensive Studies on Language, Literature, Art, and Culture, 2(1), 3539.

Anisa, H., Ansari, K., \& Solin, M. (2019). Development of poetry writing learning module assisted by religious songs for Junior High School
UNIVA Medan. Advances in Social Science, Education and Humanities, 384, 596-599.

Arifin, S., \& Kusrianto, A. (2013). Sukses menulis buku ajar dan referensi. Jakarta: Grasindo.

Borg, W. R., \& Gall, M. D. (2003). Educational research: An introduction ( $7^{\text {th }}$ ed.). New York: Longman Inc.

Daniel, I. O. A. (2013). A critical look at the teacher factor in Senior Secondary School students' poetic appreciation skills development. Theory and Practice in Language Studies, 3(2), 222-232.

Depdiknas. (2008). Kurikulum tingkat satuan pendidikan. Jakarta: Depdiknas.

Dick, W., Carey, L., \& Carey, J. O. (2005). The systematic design of instruction. New York: Longman Inc.

Fathorrahman. (2017). Kompetensi pedagogik, profesional, kepribadian dan kompetensi sosial dosen. Jurnal Akademika, 15(1), 1-6.

Khan, S., Jehanzeb, S., Ulah, I., \& Irfan, M. (2016). A stylistic analysis of "The rime of the ancient mariner." English Review: Journal of English Education, 5(1), 37-48.

Khatib, M. (2011). A new approach to teaching English poetry to EFL students. Journal of Language Teaching and Research, 2(1), 164-169.

Kim, M. K., Xie, K., \& Cheng, S.-L. (2017). Building teacher competency for digital content evaluation. Teaching and Teacher Education, 66, 309-324. doi: 10.1016/j.tate.2017.05.006.

Lestari, I. (2013). Pengembangan bahan ajar berbasis kompetensi: Sesuai dengan kurikulum tingkat satuan pendidikan. Padang: Akademia Permata.

Mahayana, M. S. (2015). Apresiasi sastra Indonesia di sekolah. INSANIA: Jurnal Pemikiran Alternatif Kependidikan, 13(3), 382-393. Doi: 10.24090/insania.v13i3.304.

Mulyasa. (2003). Kurikulum berbasis kompetensi. Bandung: Remaja Rosda Karya.

Mulyasa. (2017). Menjadi guru profesional menciptakan pembelajaran kreatif dan menyenangkan. Bandung: PT. Remaja Rosdakarya.

Nadeak, B., \& Naibaho, L. (2019). Managing lecturers' competence development at Universitas Kristen Indonesia. Proceeding: CelSciTech-UMRI, 4, 4550.

Noermanzah, \& Friantary, H. (2019). Development of competency-based poetry learning materials for class X high schools. International Journal of Recent Technology and Engineering, 8(4), 6631.

Noermanzah, N., Rais, M. N., \& Muslihah, N. N. (2013). Perbandingan penerapan strategi critical incident dengan strategi mind mapping dalam pembelajaran menulis puisi siswa kelas VIII SMP Negeri L Sidoharjo. Jurnal Perspektif Pendidikan, 7(2), 14-28.

Prastowo. (2011). Panduan kreatif membuat bahan ajar inovatif. Jakarta: Diva Press. 
Puspita, O. W., Andayani, Waluyo, H. J., \& Rohmadi, M. (2017). A needs analysis for poetry appreciation textbooks in universities: An exploratory study. American Journal of Educational Research, 5(4), 357-361.

Ritonga, A. Z. \& Halimatuhsa'diah, S. (2019). Development of poetry appreciation materials based on character education in class VII students state $2^{\text {nd }}$ Private Vocational School IX-X. IOSR Journal of Research \& Method in Education, 9(2), 39-43.

Satinem \& Juwati. (2018). Development of teaching materials of poetry writing using pictures for the elementary students. Advances in Language and Literary Studies, 9(3), 1-2. doi: 10.7575/aiac.alls.v.9n.3p.1

Satinem, S. (2015). Teaching materials model folklore in learning Indonesian based on thematic approach. IJLECR - International Journal of Language Education and Culture Review, 1(2), 27-34. doi: 10.21009/ijlecr.012.03.
Sayuti, S. (2002). Pengajaran sastra: Pengantar pengajaran puisi. Yogyakarta: Pustaka Pelajar.

Setyorini, N., \& Rizkiana, S. (2019). Pengembangan bahan ajar apresiasi puisi berbasis nilai bela negara bagi mahasiswa semester III Pendidikan Bahasa dan Sastra Indonesia di Universitas Muhammadiyah Purworejo. Lingua Rima: Jurnal Pendidikan Bahasa dan Sastra Indonesia, 8(1), 48.

Sugiyono. (2012). Metode penelitian kuantitatif, kualitatif, dan R\&D. Bandung: Alfabeta.

Sukmadinata, N. S. (2009). Metode penelitian pendidikan. Bandung: Remaja Rosdakarya.

Warsiman. (2015). The development of inductive model in learning poetry appreciation. International Journal of Social and Local Economic Governance (IJLEG), 1(1), 75-84.

Yayat, Y. (2017). Implementasi rencana program pembelajaran berbasis kompetensi pada pembelajaran kompetensi dasar menulis program CNC. Innovation of Vocational Technology Education, 6(2), 559-568. 